\title{
Women in Agriculture and Appropriate Technology in Nigeria
}

\section{A Adawo}

Department of Economics, University of Uyo, Nigeria

\section{ABSTRACT}

There is no doubt that agricultural growth in Nigeria has been on the decline. This is largely so because agricultural policies have a bias towards inappropriate technology, and fail to recognise women as the centrepiece in agriculture. The position taken in this paper is that women are in fact the pivot in Nigerian agriculture, and whatever technology is developed, should be in line with their needs. Such technology should involve a simple but mechanical form of weeding, the use of improved organic fertilizer and efficient methods of livestock husbandry.

JEL Q 10

\section{INTRODUCTION}

Women are a vital line in life, and agriculture is also a way of life.

Every economy, be it industrial or agricultural, recognises the absolute need to feeds its population. Nigeria had the historic glory of being a major exporter of agricultural produce in the 1960 s, but changed to a net importer of food during the "oil boom" of the mid-1970s. From that time till now, Nigeria has not been able to produce enough food for its teeming population. For example, food imports were $\$ 6085$.1 million, $\$ 12597.2$ million and $\$ 13,192.2$ million for 1991, 1992 and 1993 respectively (CBN, 1995: 165).

Apart from food being a necessity of life, agriculture occupies a prime position inproviding basic raw materials for some of our industries, whose capacities are regrettably underutilised mostly due to scarcity of raw materials (CBN, 1995: 92). Yet the abundant literature on agriculture has consistently pointed out that agriculture employs about 70 per cent of the country's workforce.

Invariably, Nigeria up till now depends on subsistence farmers for her food supply through traditional farming methods. At the centre of this farming 
arrangement are the women. In the rural areas of Nigeria, almost all economically active women are engaged in agriculture.

Incidentally, technological development in agriculture (if any) does not have women as the focal element in farming but emphasis has rather been shifted to cash crops and perhaps plantation farming. It is against this background that this paper sets out to link women with appropriate technology for improved farming.

\section{Statement of the Problem}

There has been a lot of policy formulation in Nigeria's agricultural sector, some of which involves or influences the mode of technology adopted for improved agricultural performance. But unfortunately these policies have failed to consider women as the centrepiece in Nigerian agriculture. This omission is to a significant extent responsible for continuous decline in agricultural production and invariably affects both the immediate family (as women produce mostly for family consumption) and the income of women.

\section{Objective of the Study}

The objective of this paper is to examine the share of agricultural work (farming) being carried out by women, which is evidence of their prominent role in Nigerian agriculture. It also seeks to identify appropriate technology that would be women-centered and cost-effective to assist the achievement of improved agriculture in Nigeria.

\section{Method}

This work makes use of secondary data from already published sources. Information on age-sex distribution of farm workers (expressed in percentages) was collected for both males and females from Federal Office of Statistics, whose publications show which sex participates more in agriculture. Moreover, information was collected on the percentage distribution of African women labour by kind of economic activity. The purpose here was to assess women's participation in productive activities, basically household activities and community work. Simple tables were used to present the information.

\section{WOMEN IN AGRICULTURE}

Women play both direct and supportive roles in traditional farming in Nigeria. They identify themselves with subsistence or peasant type of farming rather than commercial farming. This practice is prompted by their compelling need to feed 
their immediate families and thus, by extention, the very nucleus of the Nigerian society. Women participate in agriculture by growing a mixture of crops on their farmlands. Food crops range from cassava (Manihot utilissima), maize (Zea mays), yam (Dioscorea rotundata), plantain (Musa sapientum var. paradisiaca), banana (Musa sapientum), cocoyam (Xhanthosoma sagittifolium), melon (Citrulus (Colocynthis) vulgaris), cowpea (Vigna unguiculata (sinensis)), to rice (Oryza sativa). Vegetables include fluted pumpkin (Telfairia occidentalis), water leaf (Talinum triangulare), bitter leaf (Vernonia amygdalina), green (Amaranthus hybridus), etc. They also grow fruit trees like mango (Mangifera indica), pear - Local (Dacryodes edulis), pear - Avodaco (Persea americana), guava ( sidium guajava), etc. In livestock farming women are not left out. They rear chicken, goats and sheep using their personal labour, children and housemaids. Women also play a prominent role in food distribution. This includes: (i) getting farm products to the farm gate (sometimes this is done by carrying the produce on their heads where there are no motorable roads), (ii) taking the products to the market to sell to food dealers, and (iii) the processing of the food itself.

Table 1 Age-Sex distribution of farm workers in Nigeria (per cent) 1998

\begin{tabular}{|l|c|r|c|}
\hline \multicolumn{1}{|c|}{ Age group } & Male & Female & $\mathbf{F}-\mathbf{M}$ \\
\hline Below 15 & 8.87 & 9.12 & 0.25 \\
\hline $15-29$ & 32.99 & 37.59 & 4.60 \\
\hline $30-45$ & 29.65 & 34.74 & 5.09 \\
\hline
\end{tabular}

Source: $\quad$ Rural Agriculture Sample Survey 1986/87, FOS, Lagos, p. 68.

The author decided to concern himself with the age brackets $15-45$ years, which is in his opinion the vibrant workforce for both sexes. From Table 1 it is observed that for workers below 15 years, females outsupplied males by 0.25 , between the ages 15 and 29 the female labour supply showed a positive difference of 4.60 and between 30 and 45 years the difference 5.09 . This clearly shows that much more womenfolk participate in agriculture than men, mainly because women farm to feed their immediate family. This distribution of farm labour only concentrates on the sexes; it however ignores the important facts of work discrimination and work intensification. Detailed analysis of this would reveal that women also do most of the farming jobs, for example, clearing the bush, planting, weeding and harvesting.

Yet in most human endeavours including agriculture itself, women are discriminated against. This is done on grounds of land ownersnip, employment and educational opportunities, in technological development and agricultural services (Iniodu, 1996: 135). In a survey carried out in $1986 / 87$ by the Federal Office of Statistics (FOS) on land tenure for rural farming households in Nigeria 
by state, it was discovered that 91 per cent of the land cultivated by rural households was on the basis of ownership, about 7 per cent was rented and 2 per cent cultivated under another type of tenure. In a typical traditional African/Nigerian society women do not inherit family lands, on the logic that women themselves are inheritable. This assertion is very much open to debate. Despite this discrimination, women's participation in labour activities is still higher than that of men. Ritchie (1977: 131) and Okoji (1985: 165-73) have shown that over 50 per cent of economic activities in Africa is carried out by women.

Table 2 Percentage Distribution of African Women's Labour by Activities

\begin{tabular}{|l|l|c|}
\hline \multicolumn{2}{|c|}{ Activities } & $\begin{array}{c}\text { Percentage of } \\
\text { Women Labour }\end{array}$ \\
\hline A & Productive Activities & \\
\hline & Food Production & 70 \\
\hline & Domestic Food Storage & 50 \\
\hline & Food Processing & 100 \\
\hline & Animal Husbandry & 50 \\
\hline & Brewing & 90 \\
\hline & Marketing & 60 \\
\hline & Supply of Water & 90 \\
\hline & Supply of Fuel & 80 \\
\hline B & Household Activities & 100 \\
\hline & Raising and childhood education of children & 100 \\
\hline & Cooking for extended family & 100 \\
\hline & Cleaning, washing & 30 \\
\hline & House building & 50 \\
\hline & House repair & \\
\hline C & Community Work & 70 \\
\hline & Self-Help Projects & \\
\hline
\end{tabular}

Source: Iniodu, 1996: 133

From Table 2, it is observed that in economic activities like food processing, cleaning, and washing, cooking, brewing, raising children and childhood education, women's contribution is 100 per cent. It is equally of interest to note that in the important project of house building women contribute at least 30 per cent. 
Table 3 Degree of Involvement of Women in Agriculture

\begin{tabular}{|l|c|}
\hline \multicolumn{1}{|c|}{ States in Nigeria } & Per cent \\
\hline Anambra, Benue, Imo & 80 \\
\hline Gongola, Bormo, Plateau, Cross River & $60-80$ \\
\hline Rivers, Ondo, Bendel & $40-60$ \\
\hline $\begin{array}{l}\text { Sokoti, Kwara, Kano, Lagos, Niger, Abuja, Oyo, Ogun, } \\
\text { Kaduna }\end{array}$ & $20-40$ \\
\hline
\end{tabular}

Source: Ekwe, 1996: 151

From Table 3 it is clear that Nigerian women participate in larger numbers in agriculture than men. However, the level of participation thins down in the Northern states and Central South, probably because of religious/cultural reasons. The mean value of women participation in agriculture is approximately 60 per cent. As quoted by Ekwe (1996: 150) in World Development (1978: 2), the level of women's participation in agriculture is 80 per cent in Africa, 70 per cent in Asia and 45 per cent in Latin America. According to Federal Office of Statistics (FOS, 1984) 86 per cent of rural households in Nigeria work in agriculture, 50 per cent in livestock husbandry and 4 per cent in fishing.

\section{APPROPRIATE TECHNOLOGY}

Early American technology primarily depended upon the skills of the artisan. Most of these skills were ages old, as were the basic tools of trade. "Skill was the great requirement in this pattern of technology, e.g. anyone who had seen a barrel knew how the staves had been curved and shaved to produce a tight vessel. The design was wholly without mystery" (Hindle, 1970: 9).

This assertion confirms what might be described as the bedrock of technology, that is, developing technology from the available skills.

Pre-independence agricultural policy favoured export crops and resulted in the modernisation of cash crop production for export to Britain. This brought improvements to the cash crop sub-sector at the expense of food crops produced predominantly by women, consequently impoverishing the women. If food crop production is to be emphasized, extention workers must interact with the food producers proper - the women. The necessary supporting services must be compatible with appropriate technology, and this follows from the translation of relevant policies into action.

Technology can be developed by innovation, stolen or derived from adaptation. Pursell (1980: 2) states that "...machines would have to replace hands if jobs 
were to be done." Technology that develops from innovation and indigenous skills is most enduring and suitable to the environment. Ogundinkpa (1985: 8) advocates adaptive technology and lists five steps to successful adaptation:

(i) There must be awareness of the existence of the technology.

(ii) There should be development of interest in technology. Such technology should be able to solve the problems or the needs of the recipient country.

(iii) The adapted technology should be one that emphasizes the welfare of the masses or group interest, not the benefits of a few or the ruling class only.

(iv) There must be encouragement and empowerment to adapt the technology as perfectly as possible.

(v) The final stage is the adoption of the technology, sequential to its responsiveness to the needs of the people.

Incidentally, past encouragement of technology in the direction of increased agricultural output emphasized mechanised farming, plantation farming and intensive farming with heavy use of non-organic fertilizer. This arrangement has some flaws: mechanised farming needs large tracts of land which the real farmers - women - do not possess. Plantation farming is most suited to tree crops most of which do not directly provide food.

Application of fertilizer to intensive farming requires capital that most women farmers cannot afford. In summary, the agricultural technology so far adapted in Nigeria largely bypassed the real farmers. This (in addition to the DutchDisease problem of petroleum) inadvertently affected the food supply of the nation negatively.

Appropriate technology that is required should de-emphasize inorganic fertilizer, and evolve a process of preparing organic fertilizer than women themselves can participate in, practice, and apply. Instead of depending on herbicides that are alien to local vegetation, it would be desirable to produce a hand-motor weeding machine light enough to handle, easy to operate and to repair, and cheap to buy.

Seminars should be organised that carefully and meticulously teach the women seed multiplication and how to improve their quality. The agricultural extension officers should be prepared and able to do this. Improved techniques of livestock husbandry should also be taught to the women. Agricultural research 
in this direction goes with immense benefits as the thus acquired skills are likely to be passed on to future generations.

\subsection{Appropriate Technology and Agriculture}

Development of technology emanates from industrial policies, and such policies have not been lacking in Nigeria. The fact that Nigeria has not been technologically successful may well be a by-product of wrong policy assignment or poor implementation - or both.

Spencer (1970) recognises technology as a dynamic force or catalyst for desirable change towards a nation's increase in wealth. Tokaty (1975: 2) emphasizes the method and application of technology with the end result of value. This is supported by Umenyi (1982: 52) and Onyeonwu (1982: 43). It has been fashionable to emphasize advantages of latecomers to the technological domain in this context. The issue at stake is the much discussed transfer of technology, which has of course not been unopposed. So it is, because technology is a prized commodity and its intentional transfer is the least thinkable. However, for example Hoelscher (1969: 365) and Balz (1977: 269) (apostles of technology transfer) have been disproved, as the technology gap is still wide between the developed and the developing economies. Ogundinkpa (1985: 8) has thus stated that in economies with over 70 per cent of the population in agriculture, the experience of imported technologies has taken little or no cognisance of their unique needs.

\section{CONCLUSION}

To sum up, the bulk of agriculture in Nigeria is in the hands of women. It is therefore unfortunate that in terms of policy formulation, technology acquisition and application, land and credit allocation, women have been completely left out. This omission, the author of the paper believes, is one of the main reasons why agricultural productivity is on the decline.

In other words, agricultural policies in Nigeria over time have not focused on women as the centrepiece of agriculture. Women have been bluntly denied land inheritance and sometimes land acquisition, and this is a serious barrier to agricultural productivity. The little effort made in the direction of agricultural technology has centred on mechanised farming, plantation farming and application of inorganic fertilizer. The arrangement has typically excluded women and this kind of discrimination has been counterproductive. 
Even agricultural credit grants to a few fortunate applicants hardly ever include the women. Yet again, one serious problem of agricultural productivity is the oversight of the real farmers - women. It is thus proper to conclude by recalling a statement of Poullain as quoted by Reiss (1990: 11): "... because natural powers had remained uncontaminated in women by the violence inculcated in men by the process necessary for the implementing of civil society, the evolution of that society now requires that women take leading roles." $\mathrm{He}$ continued that Society might otherwise destroy itself. This is not less true of agriculture in Nigeria.

\section{REFERENCES}

1 BALZ, D.J. (1977) "Exporting Food Monopolies", Readings: Economics Guilford, Connecticut Dushkins Publishing Group, Inc.

2 CBN (1995) Central Bank of Nigeria, Annual Report and Statement of Accounts.

3 EKWE, S.N. (1996) "Women in Agricultural Production in Nigeria", in Yomi Oruwari (ed.), Women Development and the Nigerian Environment, Ibadan, Vantage Publishers, (Int) Ltd.

4 FOS (1987) Rural Agricultural Sample Survey, Federal Office of Statistics, Lagos.

5 HINDLE, B. (1980) "The Artisan During America's Wooden Age", in C W Pursell Jr. (ed.), Technology in America: A History of Individuals and Ideas, Washington D.C. Voice of America Forum Series.

6 HODSCHER, H.E. (1969) "Technology and Social Change", Readings in Economics American Society for the Advancement of Science, Vol 166.

7 INIODU, P.U. (1996) "Women in Agriculture and Rural Development in Eastern Nigeria", in Women in Africa and the African Diaspora: Bridges Across Activism and the Academy, Indiana University, Indianapolis.

8 OKOJI, E.C. (1985) "The Role of Women in Arable Cropping Enterprises in Farming Communities of Southeastern Nigeria: A Case Study", Development and Peace, 6 (Autumn): 165-73.

9 ONYEONWU, R.O. (1982), "Technology Transfer for NigerianConstraints and Prospects", Proceedings: Second Herbert Macauley Memorial Lectures, Nsukka, University of Nigeria.

10 PURSELL, C.W. Jr. (1980) "Technology in America: An Introduction" in C W Pursell Jr. (ed.), A History of Individuals and Ideas, Washington D.C. Voice of America Fonum Series.

11 REISS, T.J. (1990) "Revolution in Bounds: Wollstonecraft, Women, and Reason" in Linda Kauffman (ed.), Gender \& Theory Dialogues on Feminist Criticism, Oxford, Basil Blackwell Ltd. 
12 RITCHIE, J.A.E. (1977) "Impact of Changing Food Production, Processing and Marketing Systems on the Role of Women", Proceedings: The World Food Conference of 1976, Ames, lowa: The lowa State University Press: 129-44.

13 SPENCER, D.L. (1970) Technological Gap in Perspective, New York, Spartan Books. 